\title{
Genealogy
}

\section{Finding roots on the Web}

\author{
by Thomas Jay Kemp
}

$\mathrm{W}$ ithout a doubt, we live in exciting times. The Internet is expanding our virtual collections and allowing us to offer service we never could before. In particular, the Internet is providing practical reference tools for genealogical research from around the world.

Now every librarian can provide valuable reference assistance no matter how large his or her genealogical collection is. From full-text books, documents, and journals to massive indexes like the Social Security Death File Index, we can instantly provide current, accurate information for beginning or experienced genealogists.

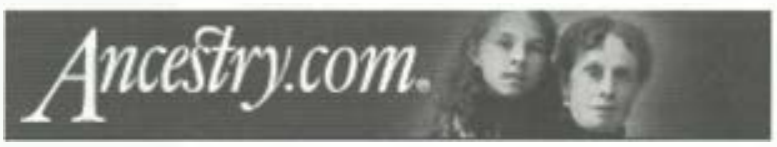

The growing number of discussion groups also provide a painless way for librarians to improve their awareness of genealogical reference sources and gives us a quick way to reach out to colleagues when we are stuck on a research question.

This column gives you the key resources, discussion groups, and Web sites for helping students and researchers interested in documenting their family trees.

\section{Discussion groups and mail lists}

- Ancestry Daily News. This free newsletter will quickly keep you up-to-date with feature stories, columns, and tips. Access: http://ancestry.com/whatsnew.htm.

- Archives. This mail list, popular with archivists and librarians, is heavily used to keep colleagues informed about archival is- sues, news, and collections. If it is too much traffic for you, you can always read the messages online. Access: http://listserv.muohio. edu/archives/archives.html.

- Eastman's Online Genealogy Newsletter. This weekly e-newsletter is essential reading by all genealogical librarians. Current information, trends, and reviews of reference materials make it a valued resource. Access: http://ancestry.com/columns/eastman/ eastnew.htm.
- GENEALIB. The discussion group sponsored by "Librarians Serving Genealogists" is an essential tool for librarians wanting quick advice from other genealogical librarians. Access: http://www.cas.usf.edu/lis/genealib/ list.html.

- Family History Newsline. Sponsored by Everton Publishers, this site has a daily (five days per week) genealogical tip that librarians will find useful. Each day one online resource, upcoming conference, or similar item is featured. Access: http://www.everton. $\mathrm{com} / \mathrm{FHN} /$ index 2 .html.

- H-Local. Part of H-Net, H-Local encourages the discussion of local history topics by librarians, historical society, and museum personnel. Access: http://www.h-net.msu. edu/ local/.

\section{About the author}

Thomas Jay Kemp, author of Virtual Roots: A Guide to Genealogy and Local History on the World Wide Web, lives in Norwood, Massachusetts.

\author{
(
}

$-2$ 
Several states have discussion groups specifically for their respective state's local history and genealogy. For example in California there is:

- H-California. This discussion group concentrates on California history. Access: http://www.h-net.msu.edu/ cal/

- NORCAL (California) Genealogy Index. NORCAL focuses on genealogical research in California. Access: http://homepages. rootswel.com/ yvonne/NORCAL $\% 20$ index/.

\section{Hubsites}

- Cyndi's List. The mega-hubsite of the genealogical world. Cyndi Howells has brought together every possible site of interest to genealogists. Access: http://www. cyndislist.com.

- USGenWeb Project. Easy to use, librarians will find this a quick way to orient their patrons to the genealogical resources available for a given state, county, or city. Access: http://www.usgenweb.org/.

\section{Journals}

- Journal of Online Genealogy. This important titie includes excellent articles and reviews. Timely and easy to use, it is a quick way to keep informed. Access: http://www. onlinegenealogy.com/.

\section{Key genealogical libraries}

- Family History Library. The largest genealogical society in the world. You can access their card catalog and key databases online. If you only go to one site, this is it. It is packed with information, indexes, and practical tools. Included is the complete SourceGuide ${ }^{\mathrm{TM}}$ with hundreds of finding aids and research papers. Access: http://www. familysearch.org.

- New England Historic Genealogical Society. The oldest genealogical society and library in the country. This important Web site includes online newsletters, access to databases, and resources. Their online cata$\log$ includes "cataloged" Web sites that librarians will want to know about and that genealogists will actually want to use. Access. http://www.nehgs.org/.

- Allen County Library. One of the largest genealogical collections in the country. Genealogists from around the country regularly go on organized trips to the Allen County
Library. Access: http://www.acpl.lib.in.us/ genealogy/genealogy.html.

- Library of Congress, Genealogy Department. The Library of Congress Web site includes key finding aids as well as database indexes for genealogists. Access: http://lcweb). loc.gov/rr/genealogy/.

- National Archives and Records Administration, Genealogy Page. This outstanding site is packed with genealogical tips, guides, and practical information for obtaining federal records (census, military, passenger lists, etc.) as well as indexes like the Index to all Veterans Who Died in the Korean War, which is searchable by name or by state. Access: http://WWW.NARA.Gov/genealogy/ genindex.html.

- New York Public Library (NYPL), Genealogical Research. You can learn about the important genealogical resources of the NYPL at this site. Be sure to also see their online guide to biographical sources at http:// www.nypl.org/research/chss/grd/resguides/ biog.html and obituaries at http://www nypl. $\mathrm{org} / \mathrm{research} / \mathrm{chss} / \mathrm{grd} /$ resguicles/obit.html. Access: http://www.nypl.org/research/chss/ $\mathrm{lhg} /$ genea.html contact.

- Newberry Library. One of the prominent genealogical collections in the country, this Web site includes useful guides on ethnic groups and state and local history not easily found elsewhere. Access: http://www. newberry.org.

\section{Key reference tools online}

- Adoption Sources. The National Adoption Information Clearinghouse will assist genealogists seeking modern vital records and gives current information on state laws and procedures. Access: http://www.calib. $\mathrm{com} / \mathrm{naic} /$ adptsear/search/index.htm.

- Afro-American Sources in Virginia, A Guide to Manuscripts. This groundbreaking electronic resource opens up these manuscript collections that would otherwise be difficult to locate and use. Access: http:// rock.village.virginia.edu/plunkett/mf . html.

- Biographical Directory of the United States Congress. There are a growing number of full-text sources on the Web. This longtime standard reference tool can be easily searched online. Access: http://bioguide. congress.gov/. 
- Chinese Immigration and Chinese in the United States. This well-done $\mathrm{Na}$ tional Archives finding aid will be a good starting point for Chinese-American researchers. Access: http://www.nara.gov/regional/ findaids/chirip.html.

- Civil War Soldiers and Sailors System. This National Park Service site includes a database of more than 230,000 AfricanAmerican troops who served in the Civil War. Access: http://www.itd.nps.gov/cwss/usct. html.

- Genealogical Materials in the New Orleans Public Library. This well-done guide, now in its fourth edition, is available in print and full-text on their Web site. A good example of using the Web to clearly teach patrons what resources a library holds and how to use them. Access: http:// www.gnofn.org/ nopl/guides/genguide/ ggcover.htm.

- Guide to African-American Documentary Resources in North Carolina. Everything you wanted to know about manuscript sources for African Americans in North Carolina. Access: http://www.upress.virginia. edu/epub/pyatt/index.html.

- Louisa's World. This well-done site brings together an original manuscript diary with links to the supporting documents. A great example of how the Web will allow librarians to make their collections more accessible. Louisa Collins was a Nova Scotia farm girl who wrote the diary in 1815. Access. http://www3.ns.sympatico.ca/dmcclare/ TITLE.HTM.

- National Portrait Gallery. The Catalog of American Portraits is an excellent reference tool. Genealogists are pleasantly surprised to find that there is an extant painting or other artistic rendering of a relative. An excellent tool searchable by artist or by sitter. Access: http://portraits.npg.si.edu/.

- Social Security Death Index. The Social Security Death File Index is a basic source for assisting genealogists. Searches can be limited by city, county, or state and even modified by birth year, month, or day. Useful for beginning or advanced researchers. $A c$ cess: http://www ancestry.com/ssdi/advanced. htm.

- World Biographical Index. Sponsored by G. K. Saur, this site indexes more than 2 million biographical sketches from around the world. A handy source. Access: http:// www.biblio.tu-bs.de/acwww25u/wbi_en/.

\section{Forms}

- Census, Blank Forms. Family Tree Maker provides blank census forms that can be downloaded as needed. Handy for showing genealogists what they can expect to find in census records from 1790 to 1920 . Access: http://www.familytreemaker.com/00000061. html.

- PBS Ancestors Series. This excellent site provides straightforward instruction on beginning genealogical research as well as GIF and PDF files of the key genealogical charts and forms. Access: http://www2.kbyu. byu.edu/ancestors/.

\section{Preservation tips}

- Library of Congress. Local history and genealogy librarians are often asked for information on preserving family papers and records. The "Frequently Asked Questions on Preservation of Books and Materials" page at the Library of Congress has the answers. Access: http://lcweb.loc.gov/preserv/presfaq. html.

- Conservation OnLine, Resources for Conservation Professionals. This site at Stanford University contains everything you need to know about conservation issues from mold to emergency planning. It is an essential and easy-to-use site. Access: http:// palimpsest.stanford.edu/.

- Eastman Kodak House. If you are looking for ways to preserve family photographs and albums, this site will explain what resources are available and what your realistic options are. Access: http://www.eastman. org/4_educ/4_prsrv.html.

\section{International sites}

There are excellent genealogical Web sites for information from around the world. Librarians may now provide practical genealogical reference service for researchers from all 50 states and around the world regardless of the size of their in-house genealogical collection.

- Australian Family History Compendium. This excellent site is your gateway to the basic repositories and resources for Australian genealogical research. Access: http:// www.cohsoft.com.au/afhc/. 
- Canadian Genealogy \& History. Organized by province, this handy site will quickly open up Canadian online reference tools and point the way for further research. Be sure to see the 1871 census index for Ontario, a model for others to follow at hitp:/ www.archives.ca/db/1871/Introduction.html. Access: http://www.islandnet.com/ jveinot/ cghl/cghl.html.

- Federation of East European Family History Societies. This online research guide and reference tool will let you assist genealogists wanting to search Eastern Europe, from Armenia to the Ukraine. This authoritative site should be bookmarked by all genealogical librarians. Access: http://feefhs.org/.

- GENUKI, UK \& Ireland Genealogical Information Service. This hubsite for accessing records in the British Isles is a quick tool for getting your patron to the resources they need for his or her particular city or region. Access: http://www.genuki.org.uk/.

- National Archives of Ireland. The Archives Web site has background material for learning more about and using Irish genealogical records. Access: http://www. nationalarchives.ie/.

- Northern Ireland, General Register Office. The Register Office site in Belfast provides similar information for Irish records in that part of Ireland. Access: http://www. nics.gov.uk/nisra/gro/.

- JewishGen. As its subtitle states, it is the home of Jewish genealogy. This megasite contains databases, thorough guides, links, and tips that provide your patrons with reliable information. An essential site. Access: http://www.jewishgen.org/.

- PRO, United Kingdom. The Public Records Office in London is one of the key British repositories for genealogical research. This excellent site contains many of their Research Leaflets (full-text) and other practical reference tools. Access: http://www. pro.gov.uk/.

- Scotland, General Register Office. The GRO provides pay-per-view access to their vital records indexes and other databases. This enormous file will be popular with genealogists. Access: http://www.origins.net/GRO/.

\section{Other useful resources}

- Maps. This Lycos site is a great way to quickly provide your patron with a map to a local site. Access: http://www.proximus.com/ lycos/index.html.

- Newspapers. The Newspaper Association of America provides an easy-to-follow site for checking obituaries and articles in local newspapers. Access: http://www.naa. org/hotlinks/index.asp.

- Switchboard.com is a good source for quickly finding specific individuals or linking to others of a given surname. Access: http://www.switchboard.com/.

\section{Further reading}

- Margot Hornblower, "Roots Mania," Time Vol. 153 (April 19, 1999). Access: http://cgi.pathfinder.com/time/magazine/ articles/0,3266,22974,00.html.

- Cyndi Howells, "Tracking Your Family Through Time and Technology," American Heritage (January/February 1999). ACcess: http://www americanheritage.com/99/ feb/005.htm.

- Thomas Jay Kemp, "Best Websites for Helping Genealogists," NAGARA Clearinghouse (summer 1997). Access: http:// www.nagara.org/clearinghouse/summer_97/kemp.html.

- "I Read it on the Web," Archival Outlook (September/October 1997).

- Thomas Jay Kemp, "Online Genealogy Resources," Library Journal (July 1, 1997). Access: http://www.bookwire.com/ LJDigital.webwatch.article $\$ 3518$.

- Thomas Jay Kemp, "Online Resources: The History of Slavery," Library Joumal (September 1, 1997). Access. http:// www.bookwire.com/LJDigital/webwatch. article $\$ 3520$.

- Thomas Jay Kemp, "Roots on the Web," School Library Journal (January 1998). Access: http://www.bookwire.com/ $\mathrm{SLJ} /$ surf-for.article $\$ 6252$.

- Virtual Roots: A Guide to Genealogy and Local History on the World Wide Web (Wilmington, Delaware: Scholarly Resources, 1997): 279.

- Emily Mitchell, "Growing Your Family Tree," Time (July 13, 1998). Access: http: cgi.pathfinder.com/time/reports/genealogy/index.html. 